\title{
An Investigation of the Effect of Preschool Children's Computer Game Playing on Their Development and Behavior through the Lens of Turkish Mothers
}

\author{
Sengul Mertol Ilgar ${ }^{1, *}$, Cigdem Karakurt ${ }^{2}$ \\ ${ }^{1}$ Hasan Ali Yucel Faculty of Education, İstanbul University-Cerrahpasa, İstanbul, Turkey \\ ${ }^{2}$ Preschool Education, İstanbul University-Cerrahpasa, İstanbul, Turkey
}

Copyright $\bigcirc 2018$ by authors, all rights reserved. Authors agree that this article remains permanently open access under the terms of the Creative Commons Attribution License 4.0 International License

\begin{abstract}
The computers used in the field of education as in many other fields are used by children mostly for playing games. The present study has aimed at identifying the general attitude mothers of preschoolers hold regarding the effect of computer game playing on children's development and behaviour. The participants were volunteer mothers $(n=749)$ whose children attend preschool in Istanbul. Data was collected via a survey developed by the researchers to assess the general attitude mothers hold regarding the effect of computer game playing on children's development and behaviour. The findings show that among the participant mothers, 93\% stated that computer games cause dependency, 92.6\% stated that this is reflected in the behaviour of children, $83.5 \%$ stated that children's behaviour is affected negatively, $87.9 \%$ stated that games lead children to mimic in real life what they are exposed to in the games. $11.7 \%$ of the mothers stated that games do not interfere with family gatherings, while $67.8 \%$ stated that they do not serve to help the discharge of aggressive impulses. Still 57\% pointed out that games support the development of hand-eye coordination, and $71 \%$ pointed out that they foster the development of better and more frequent technology use.
\end{abstract}

Keywords Preschool Children, Computer Games, Mother Perspectives

\section{Introduction}

The importance of humans' early years following birth is well known. In this regard, for a mother who has brought to life a healthy baby, trying to get to know her baby from its very first days, and providing it the appropriate support for growth and development is, beyond being important, a must. Nutrition, attention and care hold a significant place in the development of the baby in this period. While research on the importance of preschool education and the relationship between preschool education and later development and success is scant in our country, the various studies conducted in other countries present important clues about the lasting impact of care and education in this period [1].

A child needs stimulants that can maximize his innate potential and present it to the world. Such stimulants comprise from all kinds of natural and environmental factors that will foster and accelerate the physical, mental, social, and emotional development of the child. If such factors are less than enough, one can observe deficiencies in the child's developmental stages, even if they are provided in the later years. On the other hand, the major knowledge and skills that are obtained in the early years through qualified and sufficient experiences increase the potential for success in the later stages of learning, besides having a positive impact on the individual's later social and emotional life [2].

Playing, the essential endeavor in a child's life, is central in preschool children's development and education. In this regard, various definitions for play can be found in the literature, and it is commonly defined as a natural learning process in which a child has fun and obtains pleasure and competency to explore [3-5]. With the emergence of the concept of play, game culture has attracted the attention of philosophers and scientists, and it has been argued that a child's play is one of the most efficient tools to get to know him [6]. Accordingly, scientists of varying theoretical backgrounds and perspectives who have been developing implementations aimed at the early childhood period, emphasize the educational value of play and propose that pedagogical implementations take place within games [7-9]. While playing, children learn many things on their own, free from the pressures of adults and the external world. They foster the development of the most needed 
individual and social competencies, and accelerate their mental and emotional development through play $[10,11]$. Therefore, playing has great impact on the development of a child, and provides the ground on which a child can acquire his skills through stimulating developmental areas. In playing games, children acquire skills such as problem solving, exploring, thinking, reasoning, sharing, communicating, power, balance, coordination, self organisation, self-regulation, obtaining values and rules, and contributing to cultural production [12-14]. An individual is never as active as he was between the years 3-6. In that period, one has great energy and his most important task is to learn. At this point,

playing gains its importance.

With the development in technology, play and play tools (i.e. toys) have also been developing accordingly. As one of the most important tools of the speed of technological development in the 20th century, computers have become indispensable to humans, parallel to the continuous increase in their areas of use [15]. In this regard, in the present era, the spheres and tools of play are also getting their share from changes and are taking their place in the lives of children [16]. Computers that are used for communication and education have become also a central source of entertainment [17]. In this day, the digital world provides children with a popular area for playing. Especially in the recent years among children and youth, computer game subtypes (cyber console games, PC games, and "online") are becoming more and more widespread every day [18].

Parallel to the spread of computer games, their positive and negative effects on children and youth are being questioned [19]. Today, children spend most of their time with computers, technological tools, and playing computer games [20]. Between ages 0-6 when development is fastest and most critical, computer games contribute much to hand-eye coordination, concentration, and problem solving. The child can enhance his learning of many concepts in daily life and education through computer games. However, on the other hand, it has been stated that playing violent video games can result in aggressive behaviour in children, and that long term playing can lead to physiological problems and negative effects on social development [18].

Tanay [21] has examined the impact of technology on children's drawings between ages 7-9. He found that technology has a certain impact on children's drawings, and that it contributes positively to drawing in children. Viadero [22] has conducted a study on 237 students from two primary schools in California, on the role of spatial abilities in learning. They have concluded that piano lessons specifically designed in combination with computer games, can foster students' comprehension of mathematics. In their study titled "The Impact of Feedback Strategies Used in Educational Software on the Learning Processes of Children Aged 5-7”, Özdener \& Yıldırım [23] found that compared to the group that they did not educate, the group that they educated using the educational software they designed based on the literature had a higher level of success in learning. In a study conducted in the U.S.A. between the years 2001-2002, the duration of computer use was found to have an effect on the motor abilities, and the cognitive and conceptual development of preschool children [24].

In another study, mothers with children aged 0-6 stated that $50 \%$ of the children between ages 4-6 spent approximately an hour with computers and playing computer games [25]. In their study, Demirer et. al. [26] compared primary school students' computer and internet use with their reading habits. The findings show that more than an hour use of computer and internet had a negative effect on students' reading habits. The content of the games and when and for how long they are played are definitive in whether computer games are good or bad. context, parents are advised to track their children as they play computer games, and to restrict the time they spend using the computer [1].

Computer games are one of the mostly played games also by preschool children. Such games can, from time to time, bother the mothers. Therefore, the present study aims to examine mothers' perspectives on children's game playing habits.

\section{Materials and Methods}

\subsection{Research Goal}

The present study aims to identify the general attitudes mothers of preschoolers hold towards the impact of computer games on children's development and behaviour.

\subsection{Sample and Data Collection}

Survey method has been used for the present study. The study examines the perspectives mothers of preschoolers hold towards the impact of computer games on children's development and behaviour. Participants were mothers of preschool children in central Istanbul in the 2017-2018 educational period. 749 mothers who volunteered were recruited for the study.

The participants were recruited using criterion sampling. Criterion sampling comprises from those people, events, objects or situations that have the necessary qualities identified in relation to the research goal [27]. The criterion identified while selecting the group was being a mother with a preschooler, as the study attempted to identify the general attitudes mothers of preschoolers hold towards the impact of computer games on children's development and behaviour. The participant mothers were briefly informed about the research goal.

A questionnaire designed by the researchers was used in the study to assess the general attitudes mothers of 
preschoolers hold towards the impact of computer games on children's development and behaviour. Prior to designing the questionnaire, an item pool was formed based on the literature review. Then the item pool was presented to expert opinion, and the experts were asked about how sufficient the items were for collecting the necessary data. This aimed at obtaining content validity. In order to assess the validity and reliability of the questionnaire, a pilot study was conducted with a group that met similar criteria.

The questionnaire designed aims at obtaining mothers' opinions on whether in preschool children, computer games contribute to the development of perception, attention, and memory, hand-eye coordination, creativity, socialization and technology use development on one hand, and whether they result in sparing less time for actual plays, learning to obtain things fast, and refraining from family gatherings on the other hand.

\subsection{Analyzing of Data}

The data obtained from the questionnaire to assess the general attitudes mothers of preschoolers hold towards the impact of computer games on children's development and behaviour was entered into the related computer program and the necessary statistical analyses were carried out. In the analyses, percentages and frequency analysis were used. The analyses were carried out using SPSS 20.0

\section{Findings}

The results obtained from the analyses of the data collected from 749 mothers in order to assess the general attitudes mothers of preschoolers hold towards the impact of computer games on children's development and behaviour are described below.

The frequencies (f) and percentages (\%) of participant mothers' replies to the questionnaire regarding computer games are as follows:

Table 1. Percentages Regarding Computer Games

\begin{tabular}{|c|c|c|c|c|}
\hline \multirow[t]{2}{*}{ Items } & \multicolumn{2}{|c|}{ (Yes) } & \multicolumn{2}{|c|}{ (No) } \\
\hline & $\mathbf{f}$ & $\%$ & f & $\%$ \\
\hline 1.Contribute to perception, attention, and memory development in children. & 334 & 44.6 & 415 & 55.4 \\
\hline 2. Contribute to the development of hand-eye coordination in children. & 427 & 57 & 322 & 43 \\
\hline 3. Contribute to the development of creativity in children. & 279 & 37.3 & 470 & 62.7 \\
\hline 4. Have a negative impact on children's socialization. & 659 & 87.9 & 90 & 12.1 \\
\hline 5. Contribute to children's self-production. & 161 & 21.5 & 588 & 78.5 \\
\hline 6. Meet children's need for alone time. & 449 & 59.9 & 300 & 40.1 \\
\hline 7. Support children's exploratory learning. & 232 & 31 & 517 & 69 \\
\hline 8. Enhance children's better and more frequent technology use. & 532 & 71 & 217 & 29 \\
\hline 9. Lead children not to spare time for actual games. & 651 & 86.9 & 98 & 13.1 \\
\hline 10. Restrain children's family time. & 662 & 88.3 & 87 & 11.7 \\
\hline 11. Lead children to use more violence. & 580 & 77.4 & 169 & 22.6 \\
\hline 12. Help children discharge their aggressive impulses. & 241 & 32.2 & 508 & 67.8 \\
\hline 13. Lead children to become detached from the real world because of the cyber world. & 655 & 87.4 & 94 & 12.6 \\
\hline 14. Lead children to obtain everything fastly and become idle. & 625 & 83.4 & 124 & 16.6 \\
\hline 15. Have reflections on children's behaviour. & 694 & 92.6 & 55 & 7.4 \\
\hline 16. Lead children to mimic in real life what they were exposed to. & 659 & 87.9 & 90 & 12.1 \\
\hline 17. Result in dependency if use is not regulated. & 697 & 93 & 52 & 7 \\
\hline 18. Have a negative impact on children's behaviour. & 626 & 83.5 & 123 & 16.5 \\
\hline 19. Lead children to become similar to the game characters. & 627 & 83.7 & 122 & 16.3 \\
\hline 20. Are used as a solution when families are tired and cannot spare time for the children. & 606 & 80.9 & 143 & 19.1 \\
\hline 21. Children prefer to spend time with their families instead of playing computer games. & 318 & 42.5 & 431 & 57.5 \\
\hline
\end{tabular}


As can be seen in Table 1, among the participant mothers, $93 \%$ stated that computer games cause dependency, $92.6 \%$ stated that this is reflected in the behaviour of their children, $83.5 \%$ stated that their behaviour is affected negatively, $87.9 \%$ stated that games lead children to mimic in real life what they are exposed to in the games. $11.7 \%$ of the mothers stated that the games do not restrain their gatherings, while $67.8 \%$ stated that they do not serve to help the discharge of aggressive impulses. Still $57 \%$ pointed out that games support the development of hand-eye coordination, and $71 \%$ pointed out that they foster the development of better and more frequent technology use.

As can be seen in Figure 1, while 55.4\% of the mothers stated that the computer games do not contribute to the development of children's perception, attention, and memory skills, $44.6 \%$ of the mothers stated that the games do contribute to such development. The ratio between those who replied "yes" and those who replied "no" can be said to be quite low. In one study, Swing et al. [28] have also proposed that children who are exposed in long durations to television and computer games suffer from difficulties with attention. Besides, a study published in the Psychological Science journal in May 2009 that was conducted with 1178 participants [29] found that computer game dependency led to problems with attention in school and violence, and that people with such dependency were two times more likely than others to have attention deficit disorders. However, some other studies show that if the games are appropriate, computer games can foster the development of sustaining attention by stimulating the mental processes related to learning. [30].

As can be seen in Figure 2, 57\% of the mothers said "yes" to the item asking whether computer games contribute to the development of hand-eye coordination in children. Considering that the recently developed computer games are games that require attention and skills besides hand-eye coordination, this can be speculated to be the reason why mothers replied in favor of games' contribution to hand-eye coordination development. Noting that computers may contribute to children's eye-hand coordination, Yavuzer [31] has stated that computers provide a comparably easy and entertaining milieu for learning.

Digital games may have the benefits of enabling hand-eye coordination, spatial abilities, imagination, and reasoning about the reasons for figures, advanced mathematical and geometrical thinking skills, envisioning objects, integrating spatial figures [32].

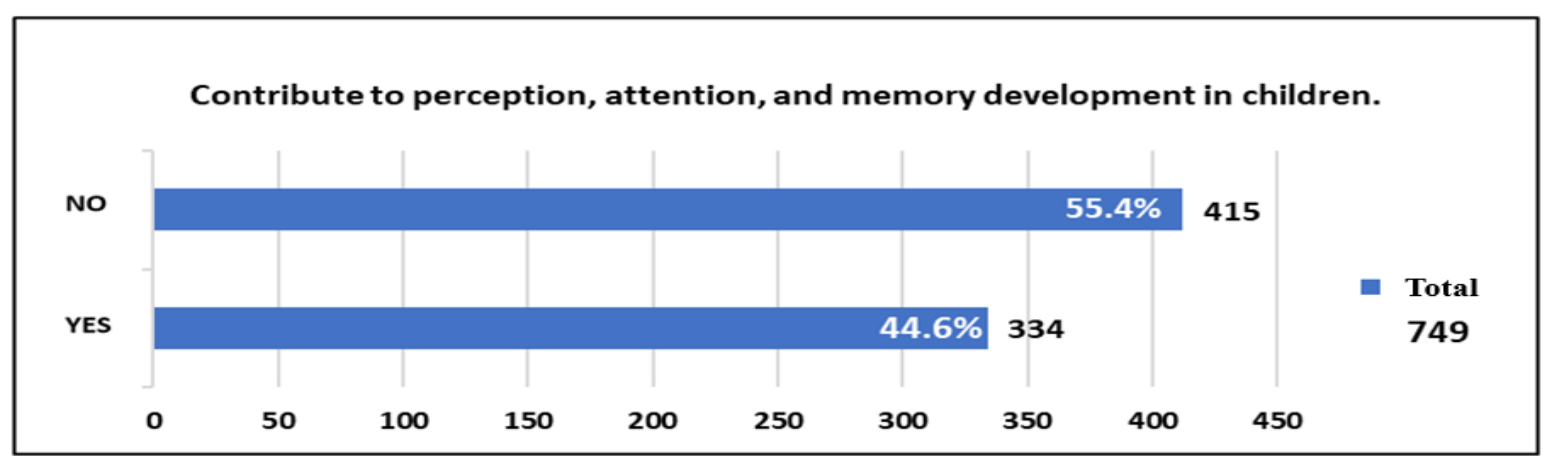

Figure 1. The Effect of Computer Games on Perception, Attention and Memory Development

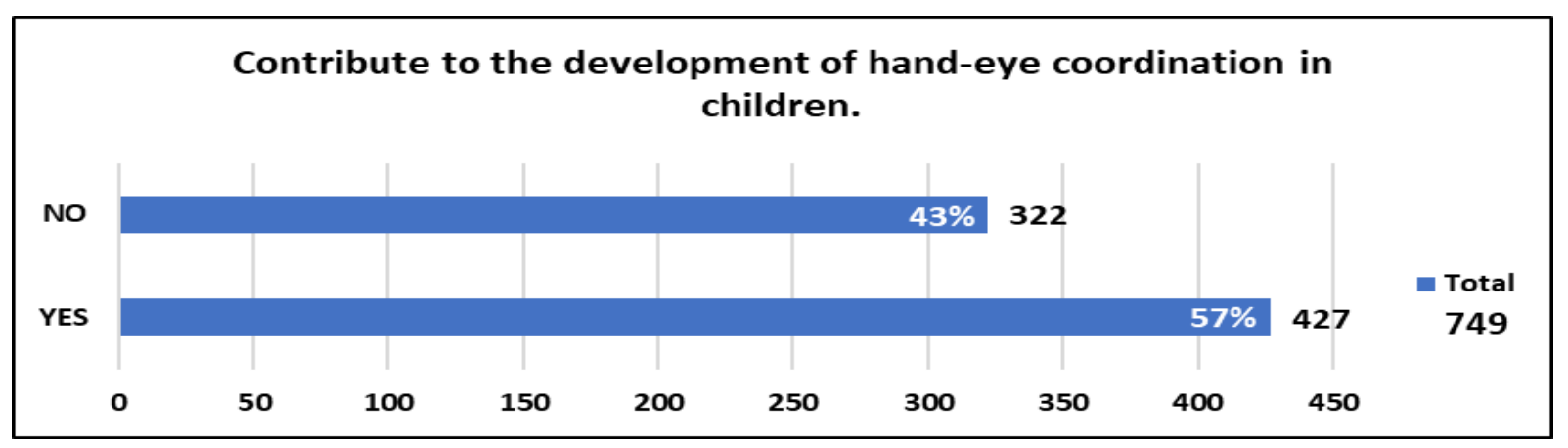

Figure 2. The Impact of Computer Games on Hand-Eye Coordination Development 
As can be seen in Figure 3, 78.5\% of the mothers said "no" to the item asking whether computer games contribute to children's self-production. Research findings suggest that computer games lead children to suffice with what is readily made by hindering their creativity while providing them worlds in which all is already set. Therefore, they may have speculated that games hinder children's self-production. Computer games are individual games that lead children to spend their time in a specific place. Therefore, they have a negative effect on children's mobility, thinking, and creativity [31].

As can be seen in Figure 4, it was indicated by $59.9 \%$ of the mothers that computer games meet children's need for alone time. Although computer games do not provide children a rich social environment, they may have speculated that games provide children gratification by enabling them to have alone time in cyber games. A study conducted with students between ages 8-18 has emphasized that a significant portion of students with computers at home prefer to stay alone. Additionally, $60 \%$ of the students spent time alone during their computer activities at school [33].

As can be seen in Figure 5, 67.8\% of the expressed that computer games do not contribute to the discharge of aggressive impulses in children. Accordingly, they may have speculated that children express their aggressive impulses through violent games, and this can help them discharge these unacceptable impulses in acceptable ways. Studies suggest that a relationship exists between violent computer games and aggressive behaviour in children [34-36]. Television, internet, video games and other similar technologies that include violent aspects are claimed to increase violence in children and adolescents [37].

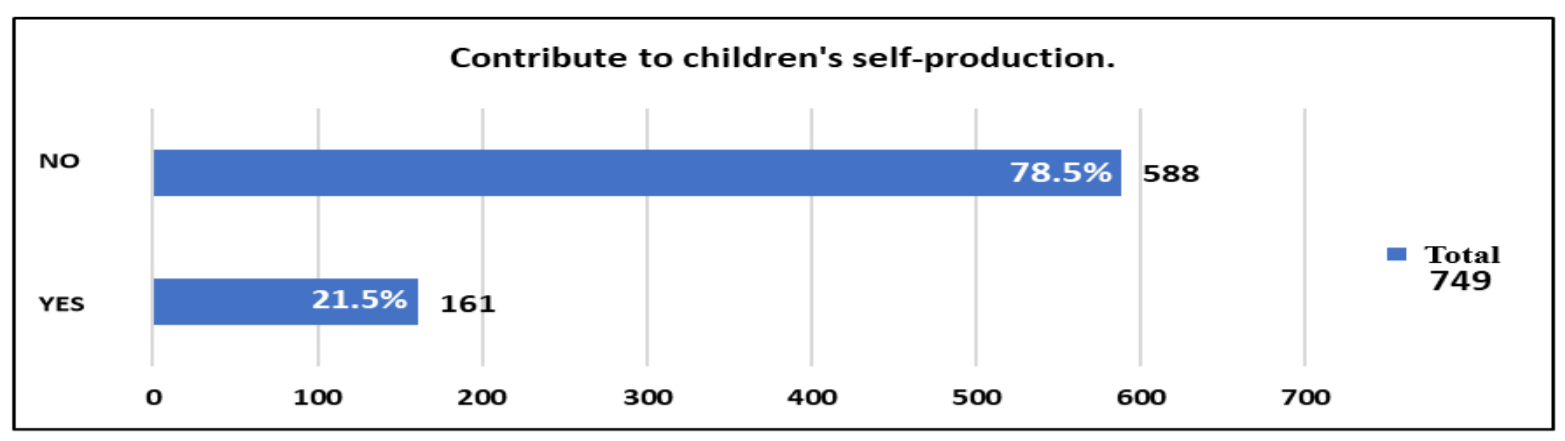

Figure 3. The Contribution of Computer Games to Children's Self-Production

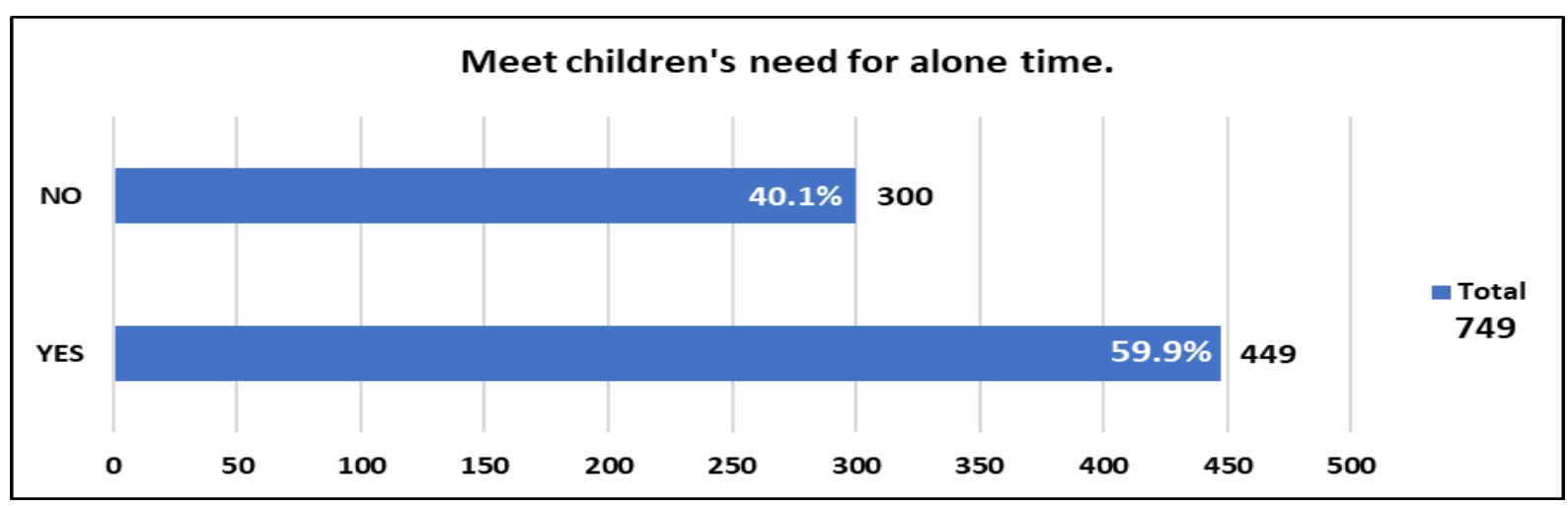

Figure 4. Computer Games Meeting Children's Need for Alone Time

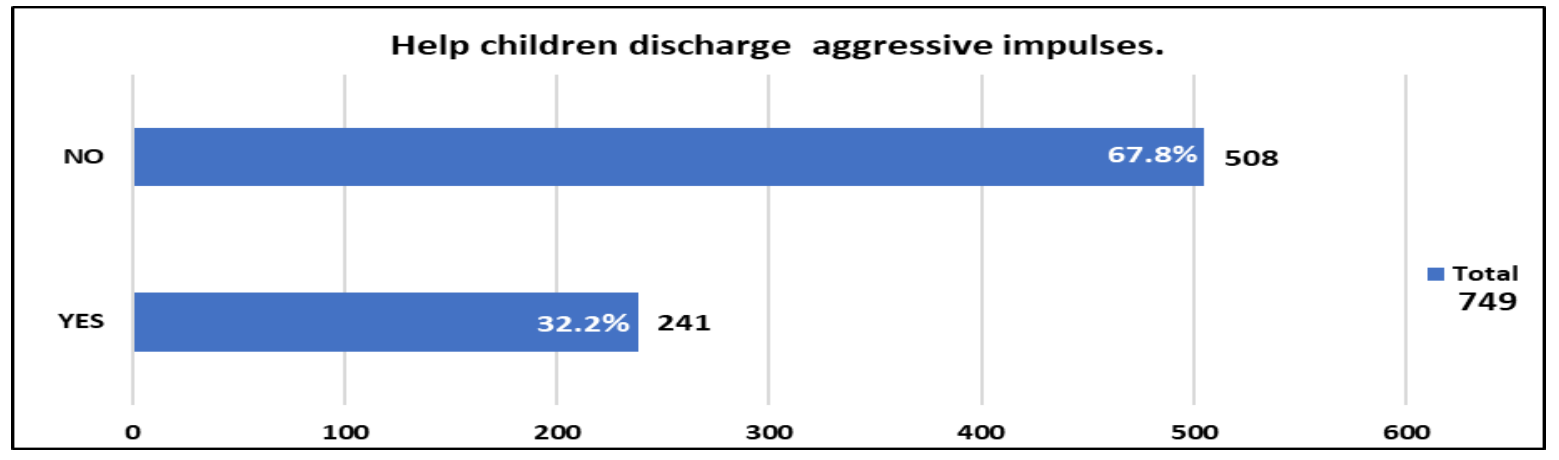

Figure 5. Computer Games Providing the Discharge of Aggressive Impulses in Children 
According to $87.4 \%$ of the mothers, the cyber world in computer games lead children to become detached from the real world (see Figure 6). The fact that children are exposed more to the cyber world than the real world prevents them from having actual experiences in the real world. This can be speculated to be the reason why mothers think that children become detached from the real world. Children who cannot distinguish the actual world from the cyber world during early childhood may act as if the violent scenes are real and can enact those scenes in everday life [38].

Figure 7 shows that $83.4 \%$ of the mothers indicate that computer games lead children to learn to obtain everything fast and become idle. It can be speculated that the mothers think that children become idle, as they are, different from actual games, not active in computer games, and as they obtain their wants with one click, without spending any energy. Studies on the harm children are exposed to when television and computers are not used as they are supposed to show that the greatest risk pertains to the hindrance of children's development and their tendency to become idle.

As can be seen in Figure 8, 83.5\% of the mothers expressed that computer games have a negative impact on children's behaviour. It can be speculated that the reason for this opinion might be that the content of certain games are inappropriate, families are unable to restrict the duration of game playing, and in this period, children have a tendency for vicarious learning. In his paper where he examines studies with children, Doğan [39] emphasizes that games do not only lead to dependency, but also have a negative impact on behaviour and brain functioning and are related to violence.

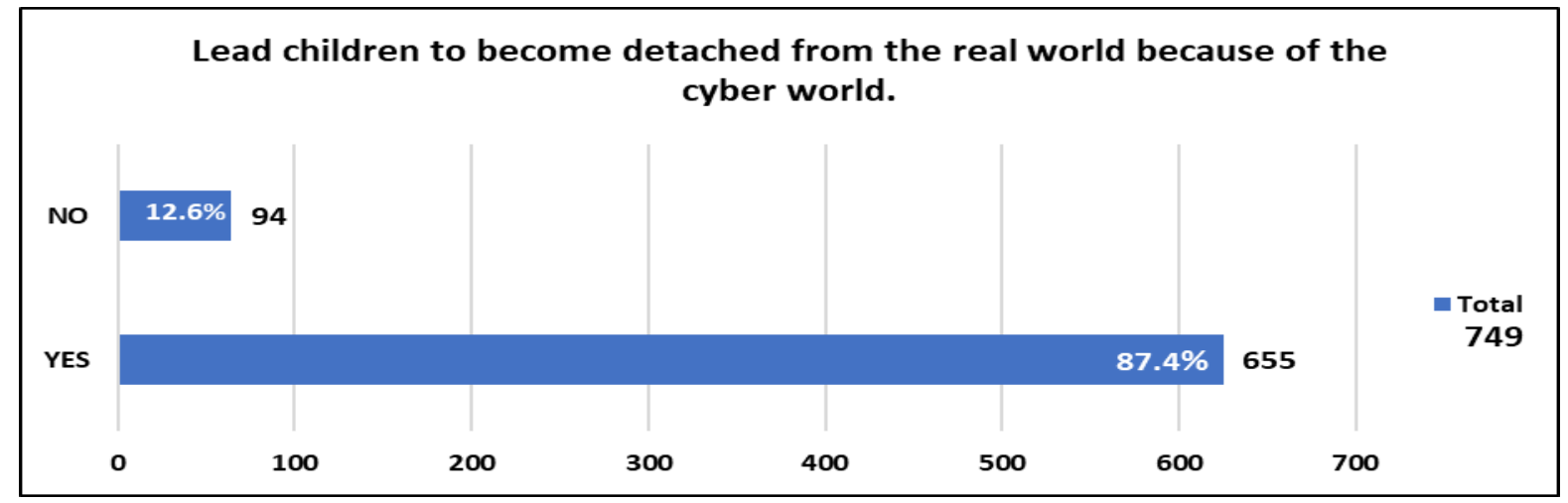

Figure 6. Computer Games Result in Children's Detachment from the Real World

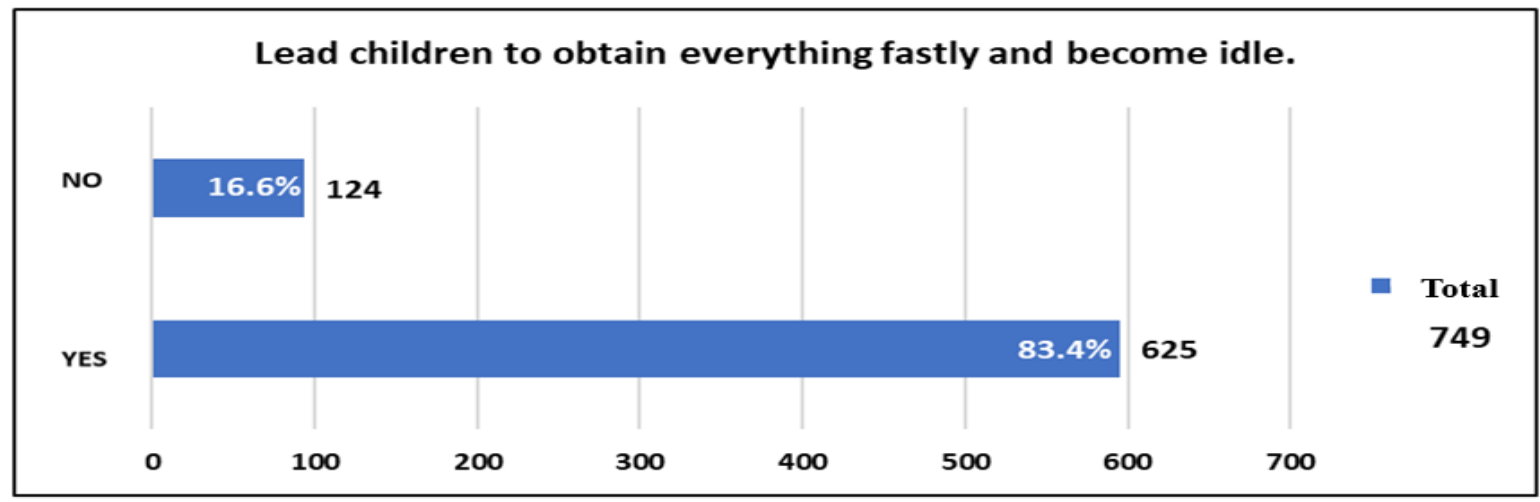

Figure 7. Computer Games Lead Children to Learn to Obtain Everything Fastly

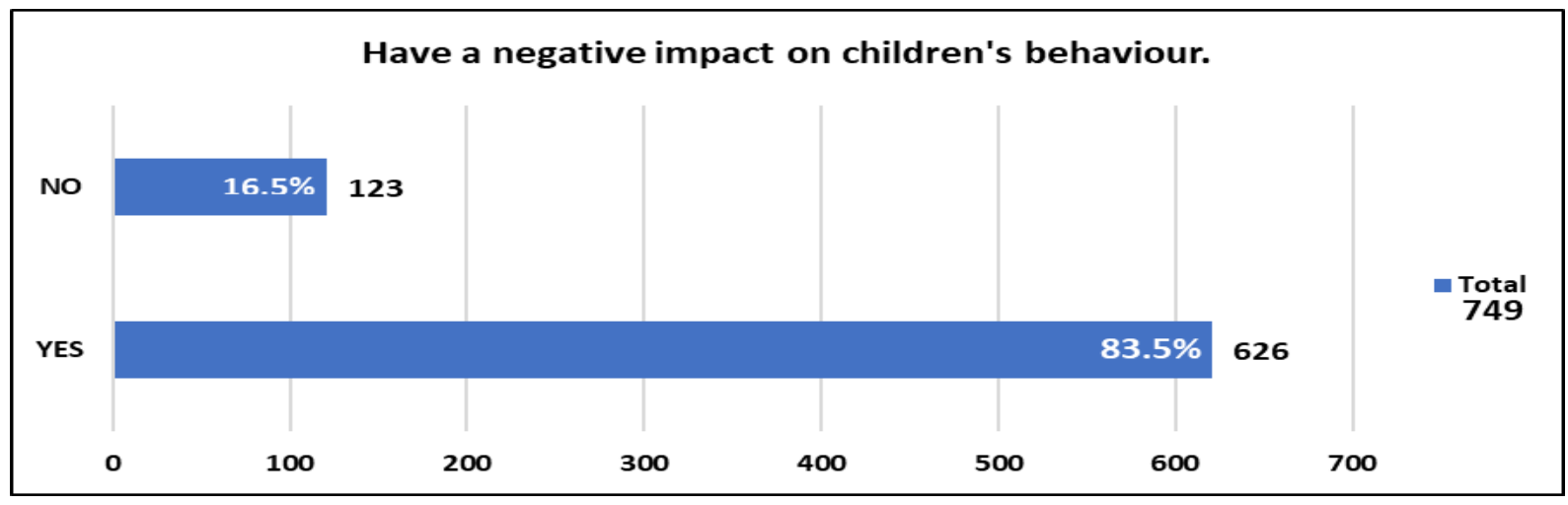

Figure 8. Computer Games Have a Negative Impact on Children's Behaviour 


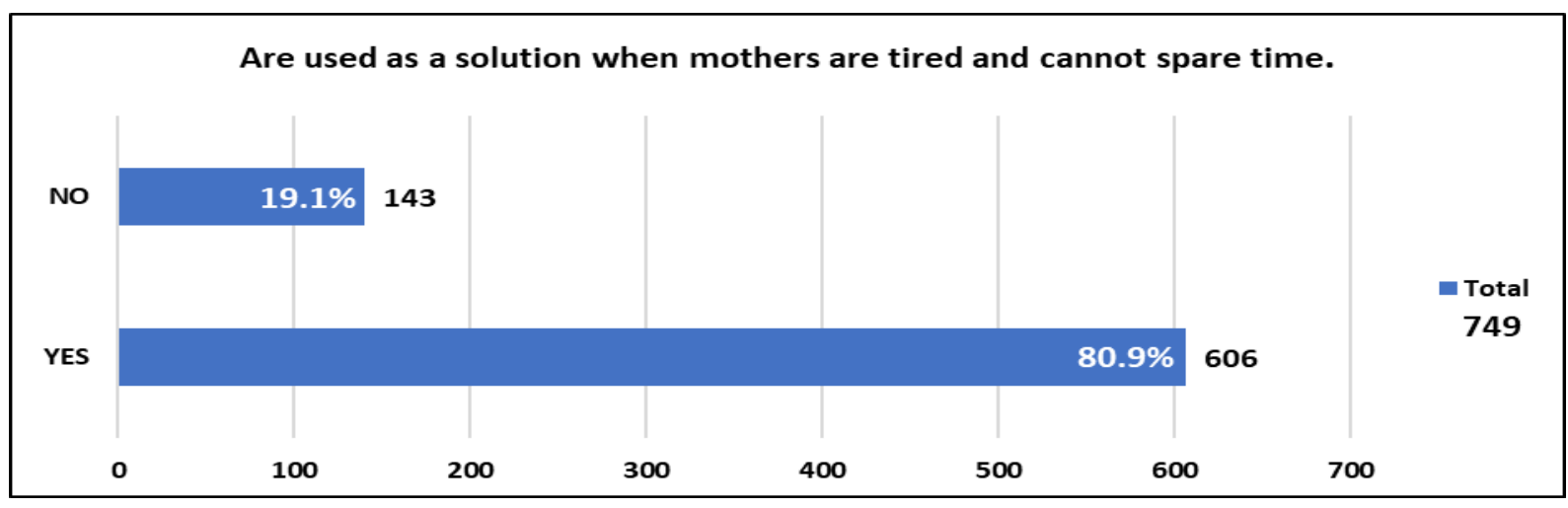

Figure 9. Computer Games as a Solution Used When Families are Tired and Cannot Spare Time

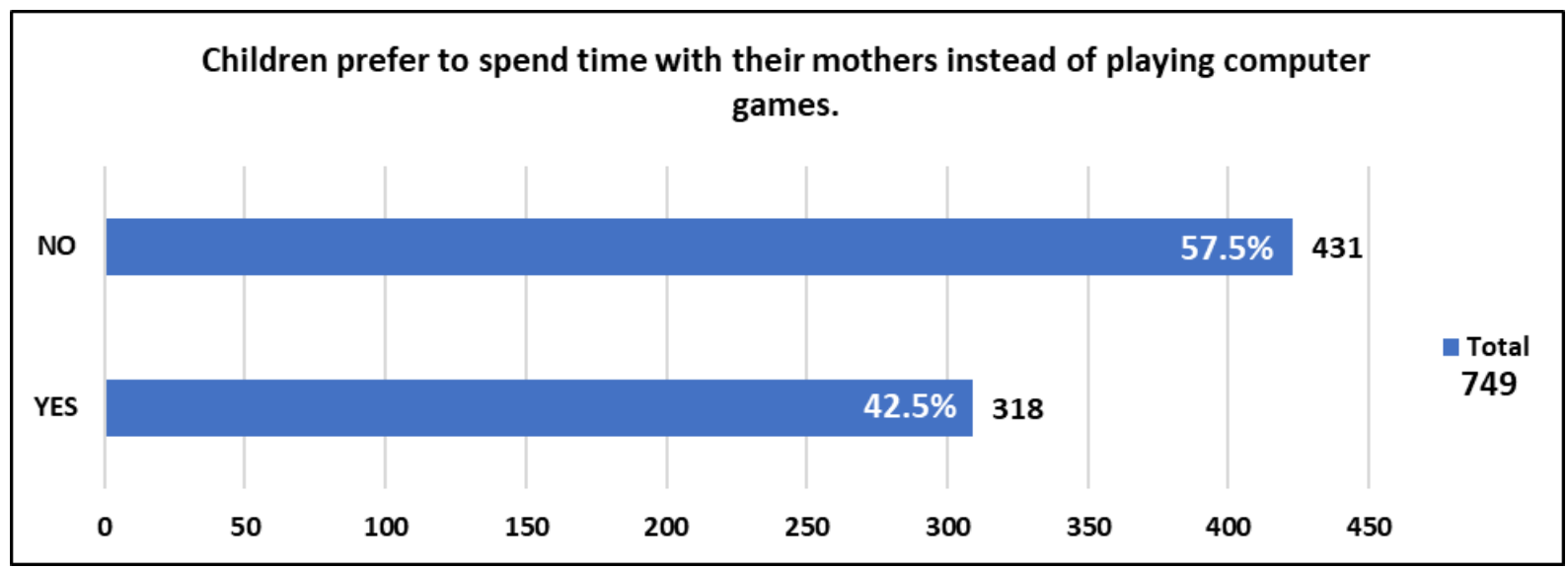

Figure 10. Children's preference to spend time with their families instead of playing computer games

It is indicated that $80.9 \%$ of the mothers think that computer games are used as a solution when mothers are tired and cannot spare time for the children (see Figure 9.). It can be said that families see computer games as a savior or as a way out when they feel tired or cannot spare time for their children.

As can be seen in Figure 10, 57.5\% of the mothers expressed that children prefer to play computer games instead of spending time with their families. It can thus be concluded that children may prefer computer games over spending time with their families, because there is no quality time available with the family. In a study conducted in Korea with 222 children going to 4th, 5th or 6th grade, the relationship between children's computer use and time spent with the family was investigated. The findings suggested that the total computer use time decreased the time spent with the family [40].

\section{Discussion and Conclusions}

The present study aimed at identifying the general attitudes mothers of preschoolers hold towards the impact of computer games on children's development and behaviour. In this study which attempted to identify the general attitudes mothers of preschoolers hold towards the impact of computer games on children's development and behaviour, the data collected from 749 mothers was analyzed to reach the following conclusions.

Among the participant mothers, 93\% stated that computer games cause dependency, $92.6 \%$ stated that this is reflected in the behaviour of children, $83.5 \%$ stated that their behaviour is affected negatively, $87.9 \%$ stated that games lead children to mimic in real life what they were exposed to in the games. $11.7 \%$ of the mothers stated that games do not restrain their gatherings, while $67.8 \%$ stated that they do not serve to help the discharge of aggressive impulses. Still $57 \%$ pointed out that games support the development of hand-eye coordination, and $71 \%$ pointed out that they foster the development of better and frequent technology use. $78.5 \%$ of the mothers replied "no" to the item asking whether computer games contribute to children's self-production. According to the data collected, computer games will lead children to suffice with what is readily made by hindering their creativity while presenting them worlds in which all is already set. This may be the reason why mothers think children's self-production is hindered. Computer games are individual games that require children to spend their time in a limited place. Therefore, they have a negative impact on children's mobility, thinking, and creativity [31]. 59.9\% of the mothers stated that the games meet children's needs 
for alone time. Although computer games do not provide children a rich social environment, they may be speculated to provide them gratification by providing alone time in cyber games. A study conducted with students between ages 8-18 has emphasized that a significant portion of students with computers at home prefer to stay alone. Additionally, $60 \%$ of the students spent time alone during their computer activities at school [33]. $87.4 \%$ of the mothers stated that the cyber world in computer games lead children to become detached from the real world. The fact that children are exposed more to the cyber world than the real world prevents them from having actual experiences in the real world. This can be speculated to be the reason why mothers think that children become detached from the real world. Children who cannot distinguish the actual world from the cyber world during early childhood, may act as if the violent scenes are real, and can enact those scenes in everyday life [38]. 83.5\% of the mothers stated that computer games have a negative impact on children's behaviour. It can be speculated that the reason for this opinion might be that the content of certain games are inappropriate, families are inable to restrict the duration of game playing, and in this period, children have a tendency for vicarious learning. In his paper where he examines studies on children, Doğan [39] emphasizes that games do not only lead to dependency, but also have a negative impact on behaviour and brain functioning and are related to violence. $57.5 \%$ of the mothers stated that children prefer to play computer games instead of spending time with themselves. It can thus be concluded that children may families because there is no quality time available with the family. In a study conducted in Korea with 222 children going to 4 th, 5th or 6th grade, the relationship between children's computer use and time spent with the family was investigated. The findings suggested that the total computer use time decreased the time spent with the family [40].

The following suggestions can be made based on the data collected in this study. The content of the games and when and for how long they are play should be considered instead of judging about whether computer games are good or bad. It is also important that the games be played alongside the guidance of the family or a teacher. It is important that a good application is chosen. Families must be analytical in this manner. A good application entertains the child, arises curiosity, comprises of attainable goals, and helps the child to learn new things. Researchers point out that parents use tablets and smartphones to soothe young children or to divert their attention. However, they also state how using such external stimuli to soothe children harms children's development of emotion regulation and self-regulation skills. Therefore, computer games should be used only for entertainment and educational purposes, and awareness should be raised in families in this respect.

\section{REFERENCES}

[1] Oktay, A. (1999). Yaşamın Sihirli Yılları: Okul Öncesi Dönem. İstanbul: Epsilon Yayıncılık.

[2] Şıvgın, N. (2005). Okul öncesi eğitim kurumlarında uygulanan eğitim programına ilişkin öğretmen görüşleri (Denizli ili Örneği). Unpublished master's thesis. Pamukkale University Institute for Social Sciences, Denizli.

[3] Casby, M. W. (2003). The development of play in infants, toddlers, and young children. Communication Disorders Quarterly, 24(4), 163-174.

[4] Özdoğan, B. (2008). Çocuk ve Oyun: Çocuğa Oyunla Yardim. 5th ed. Ankara: Anı Yayıncılık.

[5] Çetin, E. (2013). Temel tanımlar ve kavramlar. Ĕgitsel dijital oyunlar kuram, tasarım ve uygulama, 2-6. Ankara: Pegem.

[6] Tuğrul, B. (2014). Oyunun gücü. Okul Öncesi Eğitimde Oyun içinde (sf. 209-229). Ankara: Hedef Yayıncılık.

[7] Egemen, A., Y1lmaz, Ö., \& Akil, İ. (2004). Play, Toy and Children. Journal of Adnan Menderes University Medical Faculty, 5(2), 39-42.

[8] Başal, H. A. (2007). Geçmiş yıllarda Türkiye'de çocuklar tarafından oynanan çocuk oyunları. Uludă̆ Üniversitesi Eğitim Fakültesi Dergisi, 20(2).

[9] Tuğrul, B., Ertürk, H. G., Özen Altınkaynak, Ş., \& Güneş, G. (2014). Oyunun üç kuşaktaki değişimi. The Journal of Academic Social Science Studie, 27, 1-16.

[10] Rozan, N. (1997). Yaratıcı Toplum Olma Yolunda Çağdaş Eğitim. İstanbul: ÇYDD Yayınları I.

[11] Cheng, D. P. W. (2001). Difficulties of Hong Kong teachers' understanding and implementation of 'play'in the curriculum. Teaching and Teacher Education, 17(7), 857-869.

[12] Fjørtoft, I. (2004). Landscape as playscape: The effects of natural environments on children's play and motor development. Children Youth and Environments, 14(2), 21-44.

[13] Lillard, A. S., Lerner, M. D., Hopkins, E. J., Dore, R. A., Smith, E. D., \& Palmquist, C. M. (2013). The impact of pretend play on children's development: A review of the evidence. Psychological bulletin, 139(1), 1.

[14] Kennedy-Behr, A., Rodger, S., \& Mickan, S. (2015). Play or hard work: Unpacking well-being at preschool. Research in developmental disabilities, 38, 30-38.

[15] Evcin, S. (2010). Bilgisayar Oyunlarının İlköğretim İkinci Kademe Öğrencilerinin Saldırganlık Eğilimine Etkisinin İncelenmesi. Yayımlanmamış Yüksek Lisans Tezi. Maltepe Üniversitesi, İstanbul.

[16] Inan, M., \& Dervent, F. (2016). Dijital Bir Oyunun Hareketli Hale Dönüstürülmesi: Ögrencilerin Uyarlanmis Hareketli Versiyona Verdigi Tepkilerin Incelenmesi. Pegem Eğitim ve Ögretim Dergisi, 6(1), 113.

[17] Çelen, F. K., Çelik, A., \& Seferoğlu, S. S. (2011). Çocukların internet kullanımları ve onları bekleyen çevrim-içi riskler. Akademik Bilişim, 2-4. 
[18] Gürcan, A., Özhan, S., \& Uslu, R. (2008). Dijital oyunlar ve çocuklar üzerindeki etkileri. Başbakanlık Anne ve Sosyal Araştırmalar Genel Müdürlüğü, Ankara, 1-50.

[19] Ferguson, C. J. (2007). The good, the bad and the ugly: A meta-analytic review of positive and negative effects of violent video games. Psychiatric Quarterly, 78(4), 309-316.

[20] Kafai, Y. (2001). The educational potential of electronic games: From games-to-teach to games-to-learn. Playing By The Rules, Cultural Policy Center, University of Chicago, Chicago, IL, 2001.

[21] Tanay, A. D. (2011). Teknolojinin 7-9 Yaş Grubu Çocuk Resimlerine Etkisi (Erzurum İli Örneği). Master's thesis, Gazi University Institute for Educational Sciences, Ankara.

[22] Viadero, D. (1999). Research notes. Education Week, 18, 31-33.

[23] Özdener N., \& Yıldırım, Y. (2004). Eğitim Yazılımlarında Kullanılan Geri Bildirim Stratejilerinin 5-7 Yaş Çocuklarının Öğrenimi Üzerindeki Etkisi. Presented at the I. International Preschool Education Congress.

[24] Li, X., \& Atkins, M. S. (2004). Early childhood computer experience and cognitive and motor development. Pediatrics, 113(6), 1715-1722.

[25] Rideout, V. J., Vandewater, E. A., \& Wartella, E. A. (2003). Zero to six: Electronic media in the lives of infants, toddlers and preschoolers.

[26] Demirer, V., Yıldız, D. Ç., \& Sünbül, A. M. (2011). İlköğretim Öğrencilerinin Bilgisayar ve İnternet Kullanımları ile Kitap Okuma Alışkanlıkları Arasındaki İlişki: Konya İli Örneği. İlköğretim Online, 10(3). 1028-1036.

[27] Büyüköztürk, Ş., Kılıç-Çakmak, E., Akgün, O. E., Karadeniz, S., \& Demirel, F. (2016). Bilimsel araştırma yöntemleri [Scientific research methods](20th ed.). Ankara: Pegem Akademi.

[28] Swing, E. L., Gentile, D. A., Anderson, C. A., \& Walsh, D. A. (2010). Television and video game exposure and the development of attention problems. Pediatrics, 126(2), 214-221.

[29] Gentile, D. (2009). Pathological video-game use among youth ages 8 to 18: a national study. Psychological science, 20(5), 594-602.

[30] Tarhan, N. (2007). Çocuklar Bilgisayar Oyunlarından Etkilenir mi?. Tefekkür Dergisi, 19(1).

[31] Yavuzer, H. (2012). Çocuk Psikolojisi, 34th ed., İstanbul: Remzi Kitabevi.

[32] Horzum, M. B., Tuncay, A. R. A. S., \& BALTA, Ö. Ç. (2008). Çocuklar için bilgisayar oyun bağımlılı̆̆ı ölçeği. Türk Psikolojik Danışma ve Rehberlik Dergisi, 3(30), 76-88.

[33] Roberts, D. F., Foehr, U., Rideout, V., \& Brodie, M. (1999). Kids and Media@ the New Millennium: A Comprehensive National Analysis of Children's Media Use (Menlo Park, CA: Kaiser Family Foundation, 1999): At 29, chapter 4, Table 10-A. Web of Science ${ }^{\circledR}$ Times Cited, 9.

[34] Anderson, C. A., \& Dill, K. E. (2000). Video games and aggressive thoughts, feelings, and behavior in the laboratory and in life. Journal of personality and social psychology, $78(4), 772$

[35] Arriaga, P., Esteves, F., Carneiro, P., \& Monteiro, M. B. (2006). Violent computer games and their effects on state hosyility and physiological arousal. Aggressive Behavior, $32(2), 146-158$

[36] Wilson, B. J. (2008). Media and children's aggression, fear, and altruism. The future of children, 18(1), 87-118.

[37] Ulusoy, O. (2008). Ergenlerde bilişim teknolojileri kullanımı ve saldırganlık ilișkisi. Master's thesis, Cukurova University Institute for Social Sciences, Adana.

[38] Ersoy, Ö., Avcı, N., \& Turla, A. (2008). Çocuklar İçin Erken Uyarıcı Çevre: "Oyuncak, Televizyon, Bilgisayar ve Kitap. 3rd ed., Morpa Kültür Yayınları, İstanbul, 133-136.

[39] Doğan, F. Ö. (2006). Video Games and Children: Violence in Video Games. In New Symposium Journal, 44(4), 161-164.

[40] Lee, S. J., \& Chae, Y. G. (2007). Children's Internet use in a family context: Influence on family relationships and parental mediation. Cyber Psychology \& Behavior, 10(5), 640-644. 